\title{
Immunohistochemical Expression of PIT-1 Protein in Pituitary Glands of Human GRF Transgenic Mice: Its Relationship with Hormonal Expressions
}

\author{
R. Yoshiyuki OSAMURA, KoJi ODA, \\ HIROTOSHI UTSUNOMIYA, KENICHI INADA, \\ SinOBU UMEMURA, MaKoto SHIBUYA, \\ HideKi KATAKAMI*, JeFFREY W. VOSS**, \\ Kelly E. MAYO*** AND Michael G. ROSENFELD** \\ Department of Pathology, Tokai University School of Medicine, \\ Kanagawa 259-11, Miyazaki Medical College, Miyazaki 889-16, Japan, \\ **University of California, La Jolla 92093-0648, and \\ ***Northwestern University, Illinois 620208, USA
}

\begin{abstract}
It has been suggested that pit-1 protein may play a role in the differentiation of the anterior pituitary cells. The present immunohistochemical studies were designed to elucidate the relationship between functional differentiation of pituitary adenoma and expression of pit-1 protein in human $(\mathrm{h})$ GRF transgenic mice. Pituitaries from a 10 month old and a 6 month old transgenic mice were fixed in $4 \%$ paraformaldehyde and embedded in paraffin. The indirect immunoperoxidase method was performed using antibodies against hGRF, GH, PRL, ACTH, $\alpha$ subunit (SU), FSH $\beta$ SU, LH $\beta$ SU, TSH $\beta$ $\mathrm{SU}$, and pit-1 protein. Immunohistochemical double staining was performed at light and electron microscopic levels. The pituitary glands of hGRF transgenic mice (both 10 month and 6 month old) demonstrated diffuse hyperplasia of GH positive cells with coexpression of hGRF within the same cells. There were also scattered cells which were positive for other hormones and hormone subunits in the hyperplastic pituitary. Three discrete nodules were found in the pituitary gland of a 10 month old hGRF transgenic mouse and were identified as adenomas. These adenomas were composed of enlarged round cells which were positive only for GH, hGRF, PRL and TSH $\beta$ SU. Pit-1 protein was intensely expressed in the nuclei of the adenoma cells. These results suggest the existence of an autocrine mechanism by hGRF in the formation of somato-lacto-thyrotroph adenoma via constitutive pit-1 expression.
\end{abstract}

Key words: Growth Hormone Releasing Factor (GRF), Pit-1 protein, Anterior pituitary.

(Endocrine Journal 40: 133-139, 1993)

IT HAS BEEN reported that the pituitary specific transcription factor (pit-1) gene produces nucleus binding protein composed of 291 amino acids. This protein has been especially interested by various investigators because it contains 60 amino acids near the C-terminus which are homologous to those of homeodomein in Dorosophilia [1]. The

Received: August 18, 1992

Accepted: December 21, 1992

Correspondence to: Dr. R. Yoshiyuki OSAMURA, Department of Pathology, Tokai University School of Medicine, Bohseidai, Isehara-city, Kanagawa 259-11, Japan homeodomain (POU domain) is known to work in Dorsophilia as a promoting factor for their development. Simmons et al. [2] recently reported that in developing rat pituitary glands, pit-1 mRNA is distributed in all anterior cells, but that pit-1 protein is expressed in certain cells only, that is, GH, PRL and TSH cells. Human and mouse dwarfs with a mutation of the pit-1 gene have been reported to be deficient in GH, PRL and TSH secretion $[3,4,5]$.

On the other hand, human GRF transgenic mice have been reported to produce a pituitary tumor 
which is immunologically positive for human GRF and $\mathrm{GH}[6,7]$. Northern blot analysis has disclosed expression of hGRF mRNA not only in the pituitary glands but also in the liver, pancreas and gut etc. [6].

Our immunohistochemical studies are aimed at elucidating the immunohistochemical expression of hormones and pit-1 protein in hyperplasia and in adenomas of long lived hGRF transgenic mice anterior pituitary and clarifying the functional relationship between hormonal expression and pit-1 in neoplastic transformation of the anterior pituitary.

A part of this study was presented at the 74th annual meeting of the Endocrine Society, San Antonio, 1992.

\section{Materials and Methods}

Human (h)GRF transgenic mice with expressions of hGRF in various organs have been reported previously [6]. We utilized the pituitary glands from 6 and 10 month old male hGRF transgenic mice with metallothionein I promotor (one animal for each age) originated from strains established by Mayo et al. [6].

Immunohistochemical studies were done on the tissue fixed by $4 \%$ paraformaldehyde and embedded in paraffin. The indirect peroxidase method was performed by the antibodies against hormones (Table 1) and against pit-1 protein [2].

Immunoelectron microscopy (post-embedding methods) was performed on ultrathin sections using antibodies against $\mathrm{GH}$ and PRL. In brief, the tissue was fixed in $4 \%$ paraformaldehyde and embedded in LR-White plastic. Ultrathin sections were reacted with the antibodies shown above and protein A gold with gold particles of different

Table 1. List of antibodies

\begin{tabular}{llc}
\hline antibody & source & dilution \\
\hline anti-hGH & DAKO & $1: 100$ \\
anti-hPRL & DAKO & $1: 100$ \\
anti-ACTH & DAKO & $1: 100$ \\
anti-h $\alpha$ SU & NIDDK & $1: 100$ \\
anti-rLH $\beta$ SU & NIDDK & $1: 100$ \\
anti-rTSH $\beta$ SU & NIDDK & $1: 100$ \\
anti-hGRF & Katakami & $1: 600$ \\
anti-Pit-1 & Rosenfeld & $1: 400$ \\
\hline
\end{tabular}

h, human; r, rat. diameters at 10 and $20 \mathrm{~nm}$. For double labeling, two different antibodies were reacted on opposite surfaces of the ultrathin sections [8].

Serum hGRF, GH levels were measured by the sensitive sandwich enzyme immunoassay [9].

\section{Results}

The serum levels of GRF and GH were clearly elevated in a 6 month- and a 10 month-old transgenic mice compared with those of the control non-transgenic mice. Serum GRF and GH were $100 \mathrm{ng} / \mathrm{m} l$ and $800 \mathrm{ng} / \mathrm{m} l$, respectively, in a 10 month transgenic mice, and those in a 6 month old mouse were $34 \mathrm{ng} / \mathrm{m} l$ and $19 \mathrm{ng} / \mathrm{ml}$, respectively. The pituitary glands were slightly (in a 6 month old transgenic mouse) or markedly (in a 10 month old transgenic mouse) enlarged in the transgenic mice (Fig. 1).

The pituitary gland in a 10 month old transgenic mouse showed diffuse hyperplasia and three well demarcated nodular lesions (Figs. 1 and 2), whereas a 6 month old transgenic mouse revealed only hyperplastic anterior pituitary cells without nodules. The nodular lesions in a 10 month old hGRF transgenic mouse were composed of larger, less eosinophilic and more monotonous cells.

Immunohistochemically, pituitary cells in both hyperplasia and in nodular lesions expressed hGRF and GH (Fig. 3). Many cells were also positive for PRL. In the hyperplasia, there were also scattered cells positive for ACTH, $\alpha \mathrm{SU}$, and $\mathrm{TSH} \beta$ SU besides GH and/or PRL positive cell. In the nodular lesions, however, only GH, PRL and $\mathrm{TSH} \beta$ SU were demonstrated immunohistochemically (Table 2, Fig. 3). These nodular lesions showing monotonous proliferation of pituitary cells, together with characteristic hormonal expression by immunohistochemistry, were interpreted as adenomas.

Immunoelectron microscopically, by double labeling methods, the same secretory granules in the adenoma cells contained both GH and PRL (Fig. 4).

Pit-1 protein was immunohistochemically demonstrated in pituitary cells not only in adenomas but also in hyperplastic areas. Pit-1 protein was immunohistochemically specifically localized in the nuclei. The immunohistochemical expression of pit-1 protein was more prominent in the adenoma 


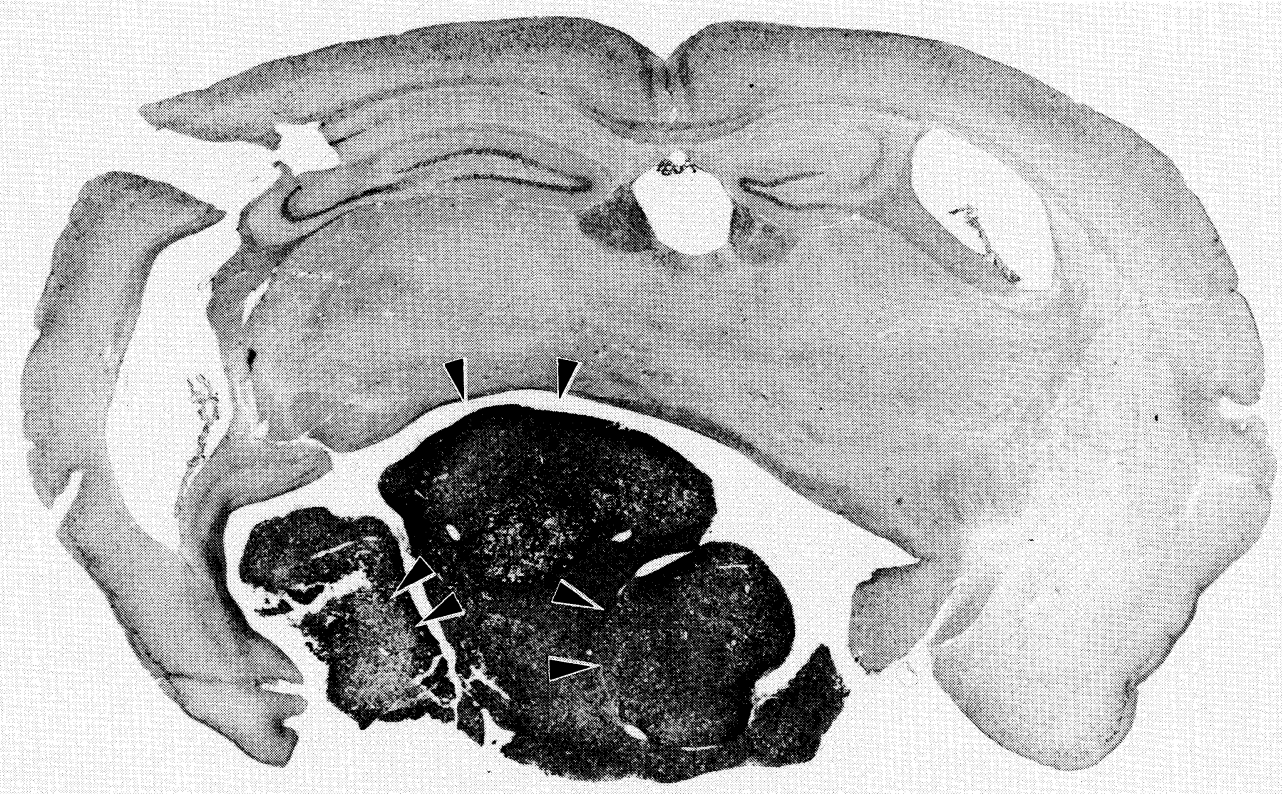

Fig. 1. Low power view of the enlarged pituitary gland in a 10 month old male transgenic mouse. Note marked enlargement of the pituitary gland containing three adenomatous nodules (arrows, $\mathrm{H} \& \mathrm{E}$ staining, $\times 13)$.

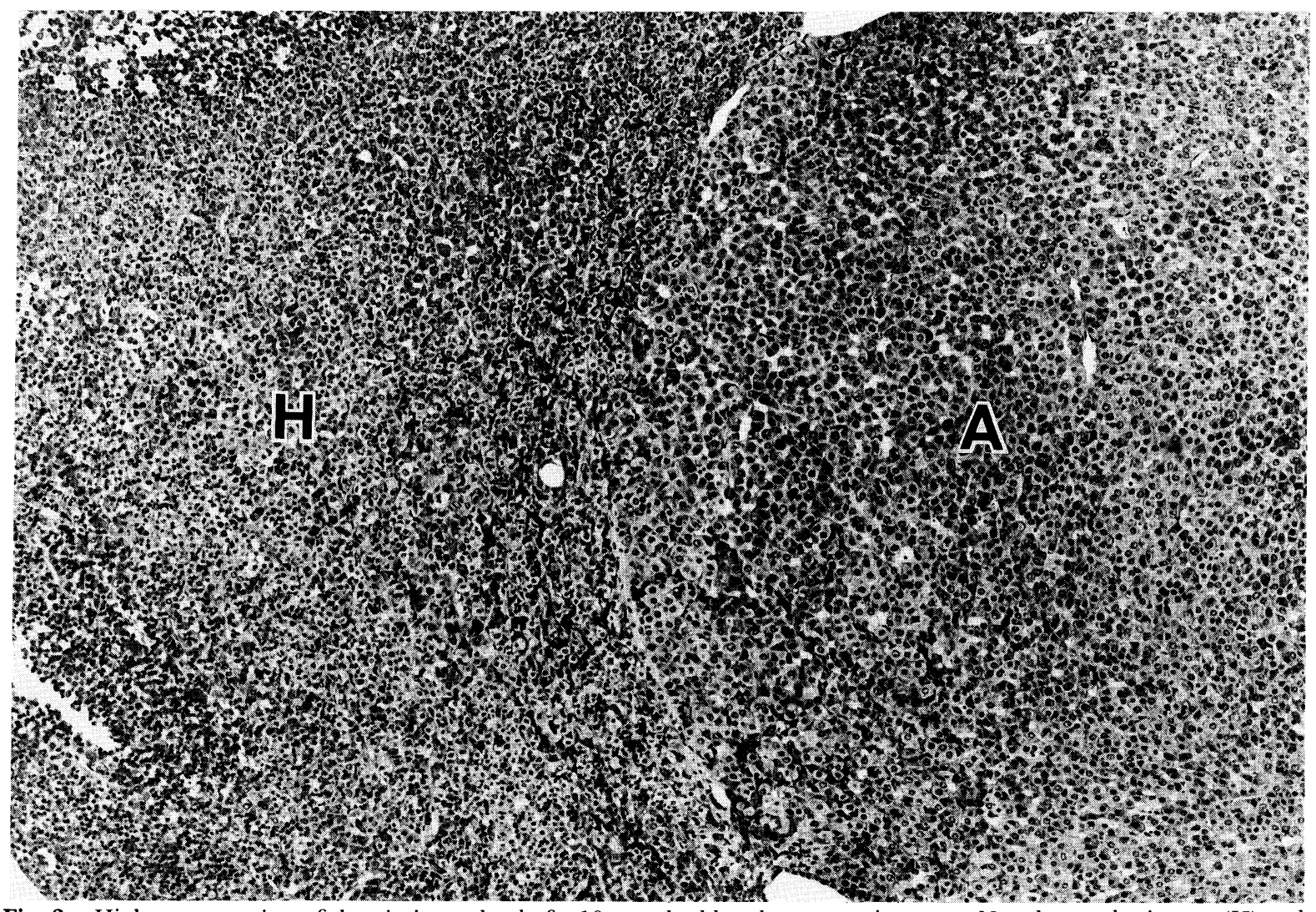

Fig. 2. Higher power view of the pituitary gland of a 10 month old male transgenic mouse. Note hyperplastic area $(H)$ and adenomatous area (A). A is composed of large round cells comparing to those in $\mathrm{H}(\mathrm{H} \& \mathrm{E}$ staining, $\times 100)$. 

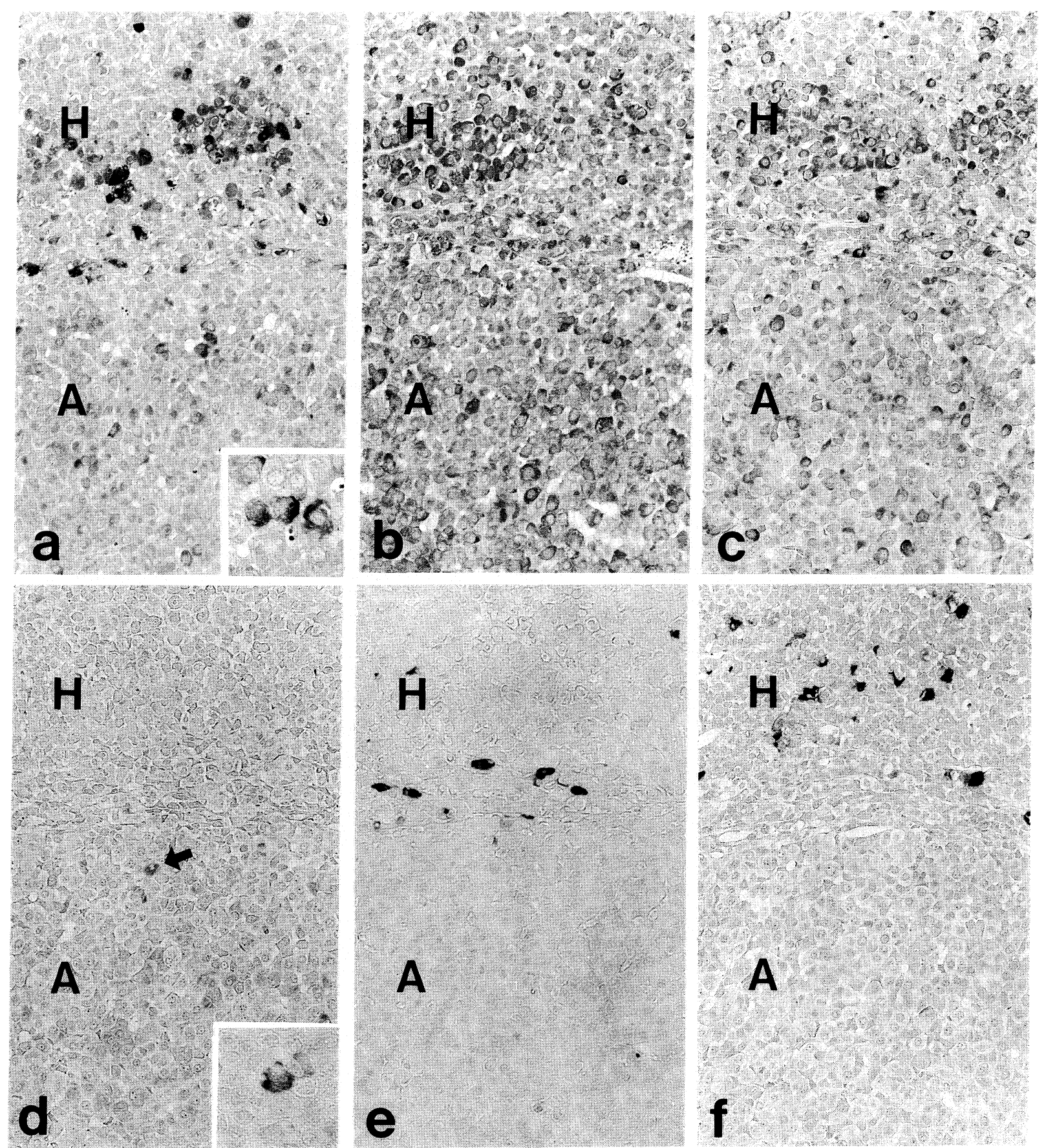

Fig. 3. Immunohistochemical staining for hGRF (a), GH (b), PRL (c), TSH $\beta$ subunit (SU) (d), $\alpha$ SU (e) and ACTH (f) in a 10 month old transgenic mouse. In both $\mathrm{H}$ and $\mathrm{A}$, many cells are positive for hGRF, GH and PRL. A is negative for $\alpha \mathrm{SU}$ or ACTH, although scattered $\alpha$ SU or ACTH positive cells are seen in $\mathrm{H}(\times 200)$. A contains scattered cells positive for TSH $\beta$ SU (arrow), but $\mathrm{H}$ contains very occasional TSH $\beta$ positive cells. Inset: adenoma cells contain GRF in the cytoplasm (a). Occasional adenoma cells show TSH $\beta$ SU in the cytoplasm $(d)(\times 300)$. 


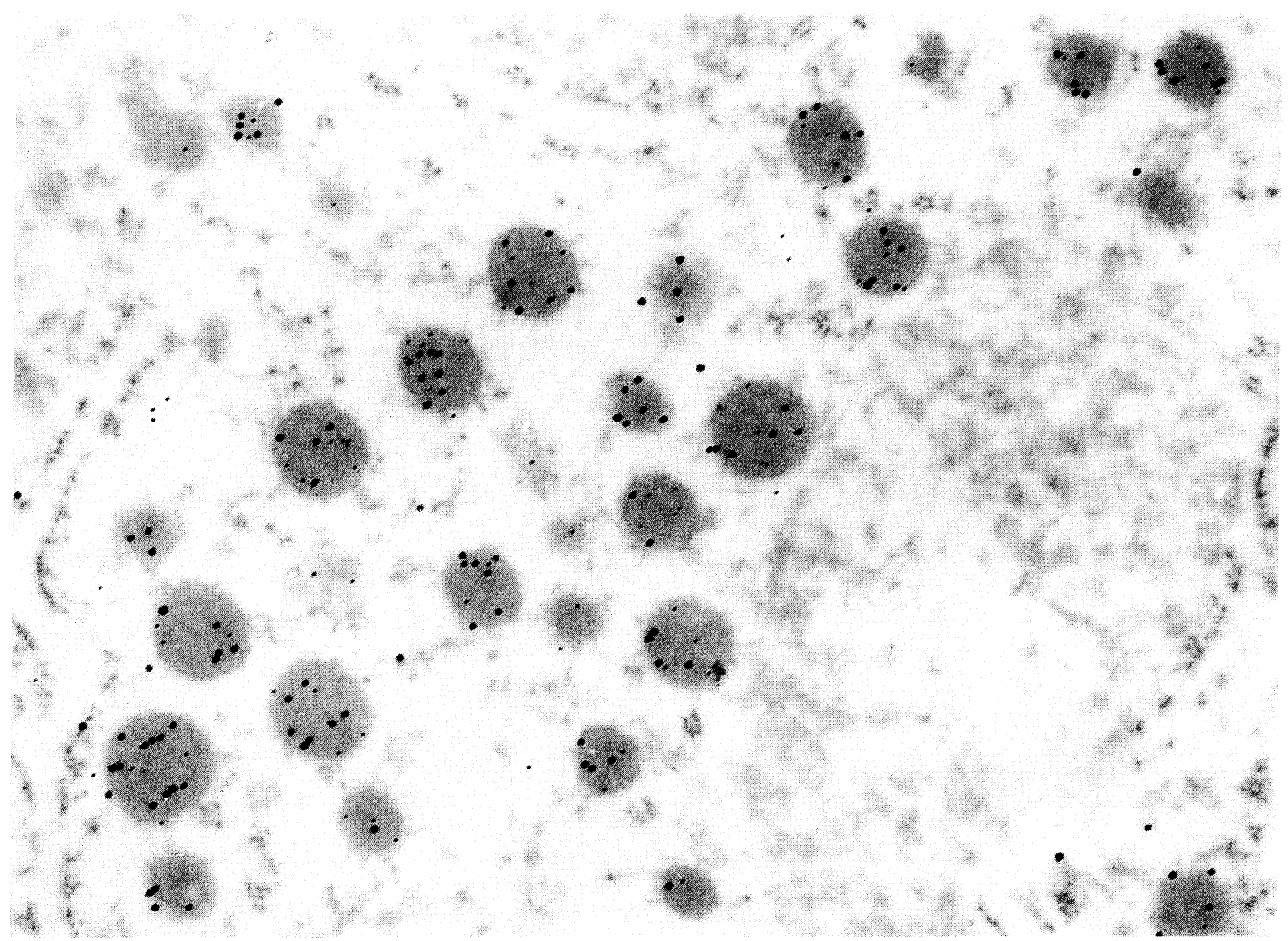

Fig. 4. Immunoelectron microscopic localization of GH and PRL in the same secretory granules in the adenomatous cells of a 10 month old transgenic mouse. Note colocalization of GH and PRL in the same secretory granules (post-embedding method. Size of Gold particles-GH: $20 \mathrm{~nm}$, PRL: $10 \mathrm{~nm}, \times 55,000)$.

Table 2. Results of immunohistochemistry

\begin{tabular}{lcc}
\hline & Hyperplastic area & Adenomatous nodules \\
\hline hGRF & ++ & ++ \\
GH & ++ & ++ \\
PRL & ++ & ++ \\
TSH $\beta$ & + & ++ \\
ACTH & + & - \\
LH $\beta$ & + & - \\
$\alpha$ SU & + & - \\
Pit-1 & ++ & ++ \\
\hline
\end{tabular}

- , negative; + , occasional; ++ , frequent.

cells in intensity and numbers (Fig. 5).

\section{Discussion}

The pituitary gland of a 10 month old male hGRF transgenic mouse had diffuse hyperplasia and three nodules. The cellular component of the latter was more monotonus than that of hyerplastic areas and showed immunohistochemical diffuse staining for hGRF, GH, PRL and TSH $\beta$ SU, but negative for $\alpha \mathrm{SU}, \mathrm{ACTH}, \mathrm{FSH} \beta$, and $\mathrm{LH} \beta$. From these findings, the nodules were interpreted as adenomas. Coexpression of $\mathrm{GH}$ and hGRF suggested the autocrine mechanism involved in the development of these hyperplastic and adenomatous lesions.

These adenoma cells were considered to be able to be a model of human $\mathrm{GH}$ secreting adenomas [10]. Electron microscopic colocalization of $\mathrm{GH}$ and PRL in the same secretory granules, which was observed in the adenoma cells in our studies, has been reported in the human pituitary somatomammotrophic adenomas [11, 12]. Specific expression of $\operatorname{TSH} \beta$ SU in the adenomas was noteworthy, because in human GH secreting adenomas, besides frequent immunohistochemical ex- 


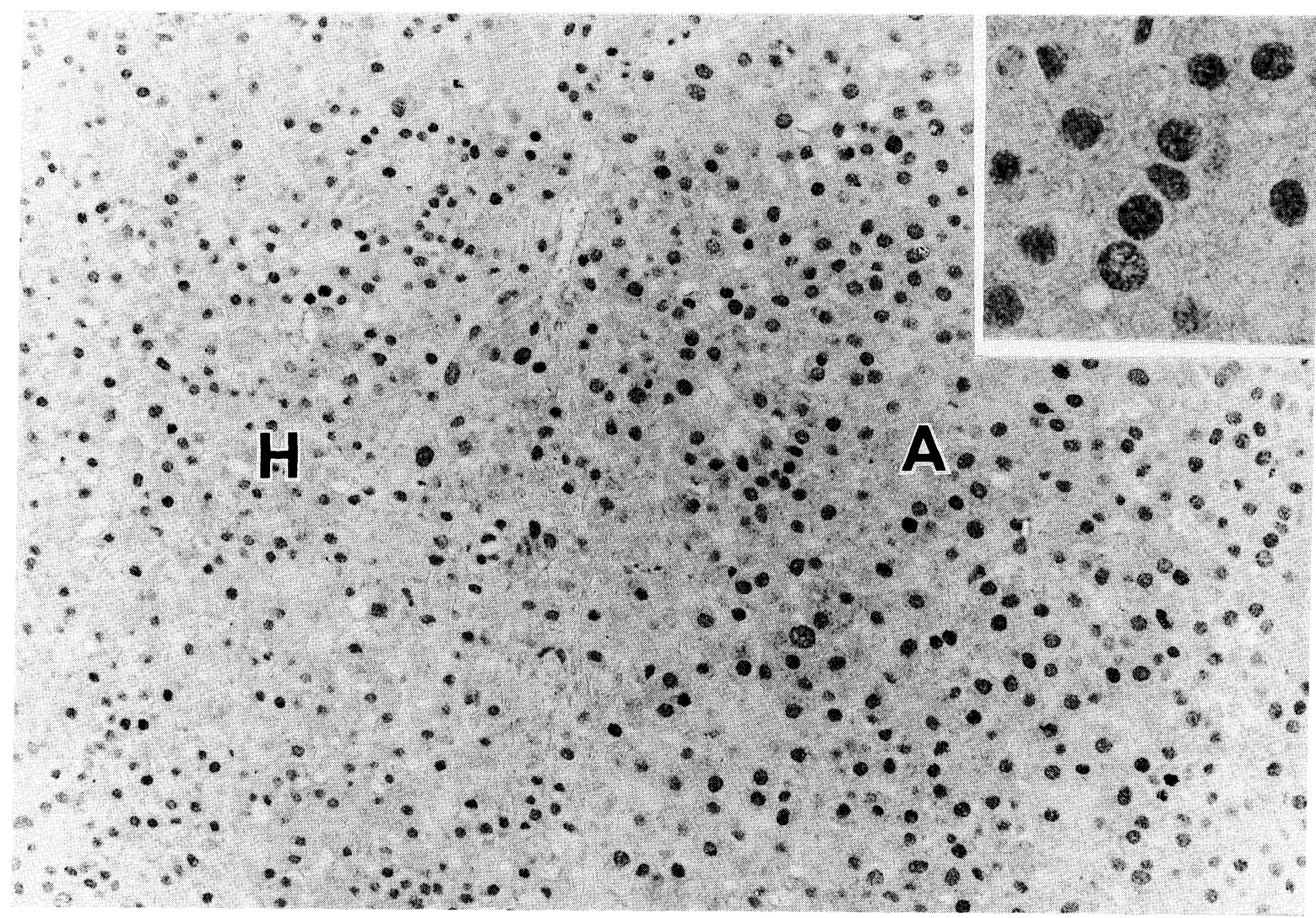

Fig. 5. Immunohistochemical localization of pit-1 protein in the pituitary gland of 10 month old transgenic mouse. Nuclear staining is observed in both $\mathrm{H}$ and $\mathrm{A}$. A shows more intense and more frequent staining comparing to $\mathrm{H}(\times 200)$. Inset: intense nuclear staining of pit-1 protein in the adenoma cells $(\times 600)$.

pression of GH, PRL, and $\alpha \mathrm{SU}$ it has been reported that some of these GH secreting adenoma cells were also positive for $\mathrm{TSH} \beta$ SU [10].

Simmons et al. reported the presence of pit-1 protein in GH, PRL and TSH producing cells of the developing and adult rat pituitary glands [2]. The adenomas in our transgenic mouse also showed positive cells for GH, PRL, and TSH $\beta$ SU as mentioned above. Immunohistochemically, pit1 protein was localized in the nuclei of increased pituitary cells both in hyperplasia and adenomatous lesions. The staining intensity was more prominent in the adenoma cells. These results suggest that pit-1 protein may play major roles in the functional differentiation of the anterior pituitary of hGRF transgenic mice and especially in the functional differentiation of the adenomas. That is, pit-1, together with neoplastic transforma- tion of the autocrine-stimulated pituitary cells, entertained more specific roles in functional differentiation toward GH, PRL, and $\mathrm{TSH} \beta$ SU production.

In summary, in long lived (10 months) hGRF transgenic mice, autocrine mechanisms of hGRF and pit-1 protein were suggested to play roles in both in the development and functional differentiation of the adenomas.

\section{Acknowledgments}

The authors thank Mr. Johbu Itoh for photographic assistance and Mrs. Yoshiko Itoh for technical assistance.

This study was supported by Research Fund 04454183 of the Japanese Ministry of Education. 


\section{References}

1. Voss JW,'Wilson L, Rosenfeld MG (1991) POUdomain proteins Pit- 1 and Oct-1 interact to form a heterometric complex and can cooperate to induce expression of the prolactin promoter. Genes Dev 5: 1309-1320.

2. Simmons DM, Voss JW, Ingraham HA, Holloway JM, Broide RS, Rosenfeld MG, Swanson LW (1990) Pituitary cell phenotypes involve cellspecific Pit-1 mRNA transformation and synergistic interactions with other classes of transcription factors. Genes Dev 4: 695-711.

3. Sen LI, Crenshaw III EB, Rawson EJ, Simmons DM, Swanson LW, Rosenfeld MG (1990) Dwarf locus mutants lacking three pituitary cell types result from mutation in the POU-domain gene pit-1. Nature 347: 528-533.

4. Ingraham HA, Di Mattia G, Rosenfeld MG, Wit JM (1992) A point mutation in the POU-specific domain of the pituitary specific transcription factor, PIT-1 results in hypopituitarism in familial human dwarfism. 74th Annual Meeting Program \& Abstracts, San Antonio, Texas.

5. Tatsumi K, Noufu T, Kaibe K, Mizuno U, Kawano S, Amino N, Miyai K (1992) Cloning of human pit-1/GHF gene and its abnormality. Folia Endocrinol Japon 68: 394 (Abstract) (In Japanese).

6. Mayo KE, Hammer RE, Swanson LW, Brister RL, Rosenfeld MG, Evans RM (1988) Dramatic pituitary hyperplasia in transgenic mice expressing a human growth hormone-releasing factor gene. Mol Endocrinol 2: 606-612.

7. Stefaneanu L, Kovacs K, Horvath E, Asa SL,
Losinski NE, Billestrup N, Price J, Vale W (1989) Adenohypophyseal changes in mice transgenic for human growth hormon-releasing factor (1989) A histological and immunocytochemical, and electron microscopic investigation. Endocrinology 125: 2710-2718.

8. Bendayan M (1982) Double immunocytochemical labeling applying the protein A-gold technique. $J$ Histochem Cytochem 30: 81-85.

9. Hidaka H, Hashida S, Katakami H, Ishikawa E, Matsukura S (1991) Sensitive sandwich enzyme immunoassay for human growth hormonereleasing hormone in plasma. Clin Chem Enzym Comms 4: 305-310.

10. Osamura RY, Watanabe K (1987) Immunohistochemical colocalization of growth hormone $(\mathrm{GH})$ and A subunit in human $\mathrm{GH}$ secreting pituitary adenomas. Virchow Arch A Pathol Anat Histopathol 411: 323-330.

11. Inada K, Osamura RY (1989) Immunohistochemical colocalization of growth hormone $(\mathrm{GH})$ and prolactin (PRL) in human pituitary adenomas associated with acromegaly-Studies by double staining technique. In: Hashino K (ed) Kyoto Prolactin Conference Monograph. Shinko Printing Co., Ltd., Kyoto, vol 5: 206-210.

12. Bassetti M, Spada A, Arosio M, Brina M (1986) Morphological studies on mixed growth hormone (GH)- and prolactin (PRL)- secreting human pituitary adenomas. Coexistence of GH and PRL in the secretory granule. J Clin Endocrinol Metab 62: 1093-1100. 